茶花（チャ, Camellia sinensis, 花蕾部）の機能性サポニン：Floratheasaponin 類の 胃保護作用と血糖値上昇抑制作用及び HPLC を用いた定性及び定量分析

\author{
吉川雅之, ${ }^{*}, a$ 王 涛, ${ }^{a}$ 杉本幸子, ${ }^{a}$ 中村誠宏, ${ }^{a}$ \\ 長友暁史, ${ }^{a}$ 松田久司, ${ }^{a}$ 播磨章一 $b$
}

\title{
Functional Saponins in Tea Flower (Flower Buds of Camellia sinensis) : Gastroprotective and Hypoglycemic Effects of Floratheasaponins and Qualitative and Quantitative Analysis Using HPLC
}

\author{
Masayuki Yoshikawa, ${ }^{*, a}$ Tao WANG, ${ }^{a}$ Sachiko Sugimoto, ${ }^{a}$ Seikou NAKAmURA, ${ }^{a}$ \\ Akifumi Nagatomo, ${ }^{a}$ Hisashi Matsuda, ${ }^{a}$ and Shoichi Harima ${ }^{b}$ \\ ${ }^{a}$ Kyoto Pharmaceutical University, shityono-cho, Misasagi, Yamashina-ku, Kyoto 607-8412, Japan, and \\ ${ }^{b}$ Harima-Kampo Co., Ltd., 4-1-45 Miyahara, Yodogawa-ku, Osaka 532-0003, Japan
}

(Received August 22, 2007; Accepted October 5, 2007)

\begin{abstract}
As a part of our characterization studies on the bioactive saponin constituents of tea flowers (Camellia sinensis, flower buds), the methanolic extract and 1-butanol-soluble portion (the saponin fraction) from the flower buds were found to exhibit potent inhibitory effects on ethanol- and indomethacin-induced gastric mucosal lesions in rats and on serum glucose elevation in sucrose-loaded rats. Among the constituents of the 1-butanol-soluble portion, floratheasaponins A, B, and C showed gastroprotective and hypoglycemic activities. Furthermore, we have developed qualitative and quantitative methods using HPLC for the principle saponins, floratheasaponins A-F, in tea flowers, which were previously found to show antiallergic and antiobesity effects. Using those methods, the saponin composition of Indian tea flowers were found to be similar to those of Chinese (Anhui) but not of Japanese tea flowers. On the other hand, it was found that the floratheasaponin contents in tea flowers varied markedly during the blooming period, and they were abundant at half-bloom. Additionally, the contents of caffeine in the tea flowers were examined using HPLC.
\end{abstract}

Key words — tea flower; Camellia sinensis; floratheasaponins; quantitative HPLC analysis; gastroprotective effect; hypoglycemic effect

\section{緒言}

チャは，ツバキ科（Camelliaceae）に属する多年 性の常緑樹で, 中国の雲南省, 四川省からミャン マーの北部にかけての地域が原産地とされている. チャは, 樹高 $3 \mathrm{~m}$ 程度になる灌木で耐寒性のある 中国種 (Camellia sinensis var. sinensis) と，喬木で 葉も大きいアッサム種 (C. sinensis var. assamica) に大別される。中国種は，江蘇，浙江省などの中国 東部から安徽, 福建省などの東南部及び日本の暖地 などで栽培されており，北インドへも移植されてい る。一方，アッサム種は，四川，雲南省などの中国 西南部，インドやスリランカ，インドネシアなどの 熱帯，亜熱帯地域で栽培されている。また，インド

$a$ 京都薬科大学, $b($ 侏ハリマ漢方製薬

*e-mail: myoshika@mb.kyoto-phu.ac.jp
シナ半島には両種の交雑種と考えられる種が存在す ると言われている.

チャの葉部（茶葉）を用いた喫茶の歴史は，少な くとも 2000 年以前にさかのぼり，当初は薬用が中 心であったと考えられている。茶葉は薬物として多 数の本草書に収蔵されており，中国明時代の「本草 綱目」（1590 年）や江戸時代の「本草食鑑」（1697 年）などにその薬効が記載されている，例えば，頭 と目を清める, 煩渇を除く, 痰を化す，食を消す， 利尿する，解毒するなどの効能があり，頭痛や目く らみ，多眠，激しい口渇を治し，去痰，消化，利尿 効果があり, 解毒作用があって下痢や二日酔いを治 療するなどと薬効が記載されている。また，種子 （茶子）には, 鎮咳, 去痰作用, 頭痛や呼吸器不善 の治療効果が伝承されている，チャの葉部や種子に サポニンが含有されていることが古くから知られて 
おり, 2-4) また，アルコール吸収抑制活性, 5) 抗菌作 用及び抗炎症作用, ${ }^{6)}$ 降圧作用7)などの生物活性が 報告されている。筆者らは，日本産（中国種）やス リランカ産（アッサム種）のチャ種子や葉部のサポ ニン成分として theasaponin $\mathrm{A}_{1}-\mathrm{A}_{7}, \mathrm{~B}_{1}, \mathrm{~B}_{5}, \mathrm{C}_{1}, \mathrm{E}_{1}-$ $\mathrm{E}_{13}, \mathrm{~F}_{1}-\mathrm{F}_{3}, \mathrm{H}_{1}, \mathrm{G}_{1}-\mathrm{G}_{2}$, assamsaponin A-I, foliatheasaponin $\mathrm{I}-\mathrm{V}$ 及びフラボノイド配糖体 theaflavonoside I-IV の構造を明らかにするととも に，甘味抑制活性，胃保護作用，肝保護作用及び脱 顆粒抑制作用のあることを見い出した. ${ }^{8-16)}$

一方, チャの花蕾部（茶花）については, 中国伝 統医学やアーユル・ヴェーダ医学などのインド伝統 医学において薬用とした記録は少なく, 近縁植物の ユチャ（アブラツバキ, C. oleifera）の花蕾部（茶 子木花）に止血作用, やけどの治療効果及びッバキ (C. japonica) の花蕾部（山茶花）に止血作用, 肝 保護作用，抗炎症作用のほか，やけど，咳嗽の治療 効果が伝承されているに過ぎない。しかし, 日本に おいては古くからチャ花蕾部（茶花）が食用にされ てきており，例えば，島根県では茶花を用いた“花 番茶”とそれを点じて食する “ぼてぼて茶”という

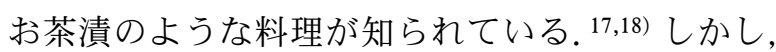
茶花の効能については明確に伝承されておらず，そ の含有成分や薬理活性についてもこれまで全く検討 されていなかつた. ${ }^{19,20)}$

筆者らは, メディシナルフラワー（薬用花）の生 体機能性成分の探索研究として，これまでに菊花 (シマカンギク花部), 21-23) マリゴールド花部, 24,25) 菩提樹 (リンデン花部), ${ }^{26)}$ 白梅花 (ウメ花部), ${ }^{27,28)}$ 三七花（サンシチニンジン花部）, ${ }^{29)}$ 山人参花（ヒ ユウガトウキ花部), ${ }^{30)}$ 山茶花 (ツバキ花部) , 31,32) 人参花 (オタネニンジン花部), ${ }^{33-35)}$ サトウヤシ花 部36)などの含有成分の化学構造を明らかにするとと もに，アルドース還元酵素阻害作用，糖負荷後の血 糖值上昇抑制作用，胃排出能抑制作用，胃保護作 用, 肝保護作用, 抗酸化作用, 脱顆粒抑制作用, 血 小板凝集作用などの薬理活性を見い出してきた。茶 花の抽出エキスについても生体機能を検討したとこ ろ，1）抗肥満作用（オリーブ油負荷における血中 中性脂肪上昇の抑制活性），19,20,37）2）抗アレルギー 作用 [ラット好塩基球白血病（RBL-2H3）細胞に おける脱顆粒抑制作用］，19,20,38）3）抗酸化作用 ( DPPH ラジカル, スーパーオキサイド消去活
性）19,20)を見い出した。そこで，日本産を始め，安 徽省，四川省，福建省などの中国各地の茶花につい て含有成分を探索したところ, caffeine, フラボ ノール（kaempferol, quercetin, myricetin など）及 びフラホノール配糖体，カテキン類 [( - ) -epigallocatechin 3-O-gallate, (-)-epicatechin 3-O-gallate, $($ ）-epigallocatechin など], フェネチル配糖体 （shimaurinoside, primeveroside など）及び assamsaponin E を単離同定するとともに, 花蕾部に特有 の 12 種の新規サポニン floratheasaponin $A-I^{36,37)}$ 及び floraltheaponin I-III,39) floraltheaflavonoside $\mathrm{A}^{39)}$ を得て構造を明らかにした。 Floratheasaponin 類には抗肥満作用, 抗アレルギー作用などの茶花エ キスで認められた薬理作用が認められ，茶花の主薬 効成分であることが判明した. ${ }^{19,20,37-39)}$ また，これ までのチャのサポニン成分の比較検討の結果, チャ においては, 葉部, 種子及び花蕾部などの部位の違 いによって，それぞれに特有のサポニンが存在する ことが判明した。

今回，筆者らは，日本産 (中国種) 茶花のメ夕ノ一 ル抽出エキス及びサポニン分画である 1-ブタノー ル移行部にエタノール及びインドメタシン誘発胃粘 膜損傷に対する抑制作用及びショ糖負荷後の血糖值 上昇抑制作用を認め，日本産茶花の主サポニンであ る floratheasaponin A（1）, B (2), C (3) に顕著な胃 保護作用と血糖值上昇抑制作用のあることを明らか にした。ささに，日本及び中国安徽省産茶花の主サ ポニンである floratheasaponin $\mathrm{A}-\mathrm{F}$ を指標物質とし た HPLCによる定性, 定量法を開発した.この定 量法を応用して，産地別と開花時期による floratheasaponin 類の含量の差異を明らかにした. また, 茶花に含有される caffeine を定量したので報 告する (Chart 1).

\section{実 験 の 部}

\section{1. 薬理試験}

1-1. 茶花エキス及び floratheasaponin 類の抽 出, 単離滋賀県産チャ花蕾部 $(1.1 \mathrm{~kg}, 2003$ 年 1 月採集）をメ夕ノール（10 1）で 3 時間加熱還流 後（計 3 回繰り返した）, 得られた抽出液を減圧下 濃縮してメタノール抽出エキス（375 g) を得た. メ夕ノール抽出エキス $(300 \mathrm{~g})$ を水 $(500 \mathrm{ml})$ に 懸濁したのち，酢酸エチル $(300 \mathrm{ml})$ で抽出し（計 

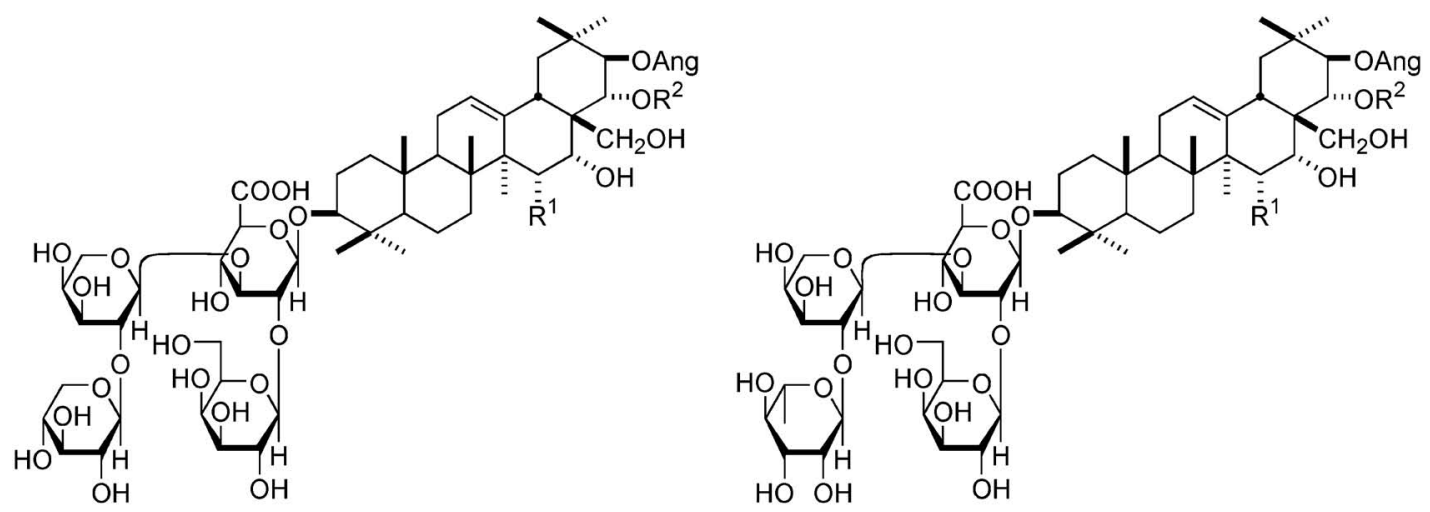

\begin{tabular}{lcc} 
& $\mathrm{R}^{1}$ & $\mathrm{R}^{2}$ \\
\hline floratheasaponin A (1) & $\mathrm{H}$ & $\mathrm{Ac}$ \\
floratheasaponin B (2) & $\mathrm{OH}$ & $\mathrm{Ang}$ \\
floratheasaponin C (3) & $\mathrm{OH}$ & $2 \mathrm{MB}$ \\
\hline
\end{tabular}

\begin{tabular}{lcc} 
& $\mathrm{R}^{1}$ & $\mathrm{R}^{2}$ \\
\hline floratheasaponin D (4) & $\mathrm{H}$ & $\mathrm{Ac}$ \\
floratheasaponin E (5) & $\mathrm{OH}$ & $\mathrm{Ang}$ \\
floratheasaponin F (6) & $\mathrm{OH}$ & $2 \mathrm{MB}$ \\
\hline
\end{tabular}

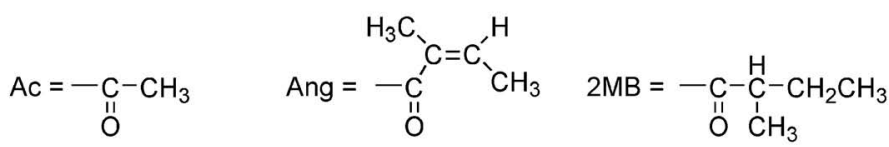

Chart 1. Structures of Floratheasaponins A-F (1-6) from Tea Flower

3 回繰り返した), 抽出液を減圧下濃縮して酢酸エ チル移行部エキス $(43.7 \mathrm{~g})$ を得た。水層を 1-ブ夕 ノール $(300 \mathrm{ml})$ で抽出後（計 3 回繰り返した $)$, 減圧下濃縮して 1-ブタノール移行部エキス（139.2 g) と水移行部エキス $(117.1 \mathrm{~g})$ を得た。1ーブタノー ル移行部エキスを文献37)記載の方法で分離精製して floratheasaponin A $(1,171 \mathrm{mg}), \mathrm{B}(\mathbf{2}, 211 \mathrm{mg})$, 及 びC $(3,121 \mathrm{mg})$ を得た.

\section{1-2. 胃保護作用}

1-2-1. エタノール誘発胃粘膜損傷モデル40,41) 18-24 時間絶食させた Sprague-Dawley（SD）系雄 性ラット（体重 240-260 g）に被験薬物を経口投与 し，1 時間後に $99.5 \%$ エタールを $1.5 \mathrm{ml} / \mathrm{rat}$ の割 合で経口投与した。 1 時間後に胃を摘出し，胃内に $1.5 \%$ ホルマリン溶液 $(10 \mathrm{ml})$ を注入して固定した のち，胃を大彎に沿って切り開き，胃体部粘膜に発 生した線状出血性病変の長さ（mm）を測定し，損 傷係数とした.

1-2-2. インドメタシン誘発胃粘膜損傷モデ ル40,41) 18-24 時間絶食させた SD 系雄性ラット （体重 240-260 g) に被験薬物を経口投与し，1 時間 後にインドメタシンを $20 \mathrm{mg} / \mathrm{kg}$ の用量で経口投与 した。インドメタシンは少量の $5 \%$ 炭酸水素ナトリ ウムで溶解後, 蒸留水, $0.2 \mathrm{M}$ 塩酸 $(\mathrm{HCl})$ を用い
中和，調製した。インドメタシン投与 4 時間後に胃 を摘出し，胃内に $1.5 \%$ ホルマリン溶液（10 ml）を 注入して固定したのち，胃を大彎に沿って切り開 き，胃体部粘膜に発生した損傷の長さ（mm）を測 定し，損傷係数とした.

なお，被験薬物は $5 \%$ アラビアゴム末溶液に懸濁 して用いた $(5 \mathrm{ml} / \mathrm{kg})$.

\section{1-3. 抗糖尿病作用}

1-3-1. アルドース還元酵素阻害活性 ${ }^{42)}$ Wistar 系雄性ラットから採取したレンズを $10 \mathrm{~mm}$ 2-mercaptoethanol 含有 $135 \mathrm{mM}$ リン酸緩衝液（pH 7.0) 中でホモジナイズし，得られたホモジネートを遠心 分離 $\left(100000 \times \mathrm{g}, 30 \mathrm{~min}, 4^{\circ} \mathrm{C}\right)$ した。その上清を 酵素分画として用いた。 反応混合液は，135 mM リ ン酸緩衝液（pH 7.0） $225 \mu \mathrm{l}$ に $1.0 \mathrm{M} \mathrm{Li}_{2} \mathrm{SO}_{4}$, 基質 として $10 \mathrm{~mm}$ DL-glyceraldehyde をそれぞれ $50 \mu \mathrm{l}$ と，酵素分画 $100 \mu \mathrm{l}$ ，サンプル溶液（DMSO Soln.） $25 \mu \mathrm{l}$ 加え予備加温 $\left(3 \mathrm{~min}, 30^{\circ} \mathrm{C}\right)$ 後, $0.3 \mathrm{~mm}$ $\mathrm{NADPH}$ を $50 \mu \mathrm{l}$ 添加し反応を開始 $\left(30 \mathrm{~min}, 30^{\circ} \mathrm{C}\right)$ した. その後, $0.5 \mathrm{~N} \mathrm{HCl}$ を $150 \mu \mathrm{l}$ 加えて反応を停 止した。この溶液中に $10 \mathrm{~mm}$ imidazole 含有 $6 \mathrm{~N}$ $\mathrm{NaOH} 0.5 \mathrm{ml}$ 加え $\left(20 \mathrm{~min}, 60^{\circ} \mathrm{C}\right)$ し， NADP を蛍 光物質に変換させた. 生成した蛍光物質を蛍光分光 光度計（PERKIN ELMER 製 LS 50B）を用いて測 


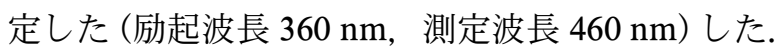

1-3-2. 小腸 $\alpha$ - グルコシダーゼ（sucrase 及び maltase）阻害活性42)

a）酵素液の調整 Wistar 系雄性ラット（体重約 $200 \mathrm{~g}$ ）の空腸から得られた刷子縁膜を粗酵素とし て用いた。刷子縁膜は $0.1 \mathrm{M}$ マレイン酸緩衝液に （pH 6.0）に懸濁し， $25-50 \mathrm{nmol} / \mathrm{ml} / \mathrm{min}$ の基質が 加水分解する濃度に希釈して用いた.

b）酵素活性の測定 基質 (maltose, sucrose，74 mM） $100 \mu \mathrm{l}$ に被験物質溶液 $50 \mu \mathrm{l}$ を加え， $37^{\circ} \mathrm{C}$ で 23 分間予備加温した. 酵素液 $50 \mu \mathrm{l}$ を加え 30 分間反 応させ, 水 $800 \mu \mathrm{l}$ を加え, 沸騰水浴中で 2 分間加 熱し, 酵素を失活させた. 別に, 各検体につき酵素 液を加えたのち, 直ちに水を加えて沸騰水浴中で 2 分間加熱し，酵素を失活させたものを盲検とした。 生成したグルコースの量をグルコースオキシダーゼ 法(グルコース CII テストワコー)により測定した. 基質及び被験物質は， $0.1 \mathrm{M}$ マレイン酸緩衝液（pH 6.0）に溶解して用いた。得られた值より $50 \%$ 阻害 する濃度（ $\mathrm{IC}_{50} ）$ を求めた。

1-3-3. ショ糖負荷ラットにおける血糖値上昇抑 制作用 ${ }^{36,42)}$ Wistar 系雄性ラット（体重約 130170 g）を 20-24 時間絶食させたのち，被験物質を 経口投与し，その 30 分後に $20 \%$ ショ糖溶液を $5 \mathrm{ml} /$ $\mathrm{kg}$ の用量で同時に経口投与した。その $0.5,1,2$ 時 間後にエーテル麻酔下（採血時のみ）にて眼下静脈 より約 $0.4 \mathrm{ml}$ ずつ採血を行い，遠心分離により血 清を分離し, グルコースオキシダーゼ法（グルコー ス CII テストワコー）を用いて血糖値を測定した. なお，被験薬物は $5 \%$ アラビアゴム未溶液に懸濁し て用いた $(5 \mathrm{ml} / \mathrm{kg})$.

1-3-4. 統計処理 数值は平均值士標準誤差 （S.E.）で表し, 有意差検定には Dunnett の多重比 較検定法を用いた。

\section{2. 定性, 定量分析}

2-1. 標品 Floratheasaponin A-F（1-6）は, 日本産及び中国安徽省産茶花から単離し, 構造決定 したものを用いた. ${ }^{37,38)}$ Caffeine 標準品は Nakalai Tesque より購入した.

2-2. 試料日本 (滋賀県, 2003 年 1 月), 中 国（安徽省, 2005 年, 2006 年 9 月), インド (West Bengal 州，2005 年 1 月）にて栽培されていた中国 種チャの花蕾部を採集した。別に第 15 改正日本薬
局方生薬試験法の乾燥減量の項に従つて乾燥減量を 求め, 換算した生薬の乾燥物に対して各成分含量を 算出した.

\section{2-3. 試料溶液の調製}

2-3-1. Floratheasaponin 類の定性，定量試料 サンプルを減圧下で $40^{\circ} \mathrm{C}, 3$ 時間乾燥させたのち, 粉末とし, 約 $1 \mathrm{~g}$ を精密に量り, $50 \mathrm{ml}$ のメ夕ノー ルを加え 30 分間加熱還流し，冷後，ろ紙ろ過し た. 残渣に $50 \mathrm{ml}$ メタノールを加え, 同様操作を 2 回繰り返した。得られた抽出液を合わせ， $40^{\circ} \mathrm{C}$ 以 下で減圧濃縮した。濃縮液にメタノールを加えて正 確に $5 \mathrm{ml}$ とし，これをメンブランフィルター $(0.45 \mu \mathrm{m})$ でろ過したものを試料溶液とした.

2-3-2. Caffeine の定量試料43) サンプルを減 圧下で $40^{\circ} \mathrm{C}, 3$ 時間乾燥させたのち, 粉末とし, 約 $0.5 \mathrm{~g}$ を精密に量り, 精製水 $75 \mathrm{ml}$ を加え, 1 時間加 熱還流した。ろ紙ろ過後, 濾液を正確に $100 \mathrm{ml}$ と した。これをメンブランフィルター $(0.45 \mu \mathrm{m})$ で ろ過したものを試料溶液とした。

2-3-3. 注入量及び計算方法試料溶液又は標 準溶液 $10 \mu \mathrm{l}$ を正確に注入し，ピークの面積法によ り計算した。

\section{2-4. 装置及び測定条件}

2-4-1. HPLC 条件 HPLC 装置： LC10AD vp Shimadzu, 検出器: SPD-10A UV-VIS detector, Shimadzu, カラムオーブン : CTO-10AC vp column oven, Shimadzu, カラム : GL Science Inc. Inertsil ODS-3.5 mm, $4.6 \times 250 \mathrm{~mm}$, Develosil C-30UG-5, $4.6 \times 250 \mathrm{~mm}$, データ処理用ソフト： Shimadzu Class vp バージョン 5.032.

2-4-2. 測定条件 1) Floratheasaponin 類の定 性分析: Develosil C-30-UG-5 カラム, 紫外吸光光 度計波長 $230 \mathrm{~nm}$ を用い, カラム温度は $40^{\circ} \mathrm{C}$, 溶離 液に acetonitrile-10 mM リン酸緩衝液 $(\mathrm{pH} 2.3)(40$ :

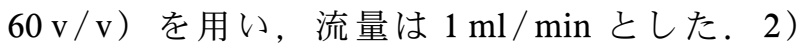
Floratheasaponin 類の定量分析 : GL Science Inc. Inertsil ODS-3.5 mm カラム, 紫外吸光光度計波長 $230 \mathrm{~nm}$ を用い, カラム温度は $40^{\circ} \mathrm{C}$, 溶離液に $\mathrm{MeOH}-10$ mM リン酸緩衝液（pH 2.3）（75：25 v/v)

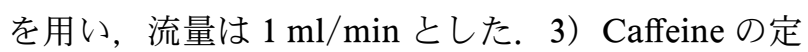
量分析 : GL Science Inc. Inertsil ODS-3.5 mm カラ 厶, 紫外吸光光度計波長 $270 \mathrm{~nm}$ を用い, カラム温 度は $40^{\circ} \mathrm{C}$, 溶離液に $\mathrm{MeOH}-2 \%$ 酶酸溶液（30:70 


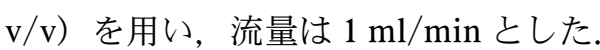

\section{2-5. 検量線の作成}

2-5-1. Floratheasaponin 類 ODS カラムを用 いて， $\mathrm{MeOH}-10$ mM リン酸緩衝液（pH 2.3）（70： $30 \mathrm{v} / \mathrm{v})$ で floratheasaponin D (4), E (5), F (6) の 検量線を検討した。 Floratheasaponin D-F (4-6) をそれぞれ 0.1-1.0 mg/ml となるように段階的に希 釈し，上記の分析条件で各標準液について HPLC 分析を行った結果，クロマトグラフのピークと注入 量の間に良好な直線関係（r=0.9992-1.0000） が得 られた。回帰方程式，相関係数及び保持時間は次の 通りであった。

Floratheasaponin D (4): Y=336162X-9326.3; $\mathrm{r}=0.9994$; 保持時間 $13.5 \mathrm{~min}$.

Floratheasaponin E (5): $\mathrm{Y}=636186 \mathrm{X}+10341$; $\mathrm{r}=1.0000$; 保持時間 $22.4 \mathrm{~min}$.

Floratheasaponin F (6) : Y $=442186 \mathrm{X}-80470$; $\mathrm{r}=0.9992$; 保持時間 $24.7 \mathrm{~min}$.

なお，Yはピーク面積，Xは標準品の絶対注入量 （ $\mu \mathrm{g} ）$ を表した.

2-5-2. Caffeine ${ }^{43)}$ Caffeine を精密に秤取し て，メタノールで $10 \mathrm{ml}$ に定容したものを 0.1-1.5 $\mathrm{mg} / \mathrm{ml}$ となるように段階的に一定濃度の標品溶液 を希橎調製し検量線を作成した。 上記条件で各標品 溶液を HPLC 分析を行った結果，いずれの caffeine のクロマトグラフのピーク面積と絶対注入量の間に 良好な直線関係が得られた。回帰方程式，相関係数 及び保持時間は次の通りであった。

Caffeine: $\mathrm{Y}=293010 \mathrm{X}-3791.5 ; \mathrm{r}=1.0000$; 保持 時間 $8.4 \mathrm{~min}$.

なお，Y はピーク面積，X は標準品の絶対注入量 （ $\mu \mathrm{g} ）$ を表した.

\section{結果及び考察}

1. 茶花エキス及び floratheasaponin A (1), B (2), C（3）の薬理作用

1-1. 胃粘膜保護作用筆者らは，日本産中国 種チャ種子及びスリランカ産アッサム種チャ種子の サポニン分画及び theasaponin $\mathrm{E}_{1}, \mathrm{E}_{2}$, assamsaponin C にエタノール誘発胃粘膜損傷の抑制作用のあるこ とを報告した. ${ }^{11)}$ 日本産茶花メタノール抽出エキス にも胃粘膜保護作用が期待されたことから検討した 結果，日本産茶花メ夕ノール抽出エキスにエタノー
ル誘発胃粘膜損傷に対する保護作用が認められた。 胃保護活性はサポニン分画である 1-ブタノール移 行部エキスに集約し，酢酸エチル移行部や水移行部 には活性は認められなかった。次に，茶花メ夕ノー ル抽出エキスについて, 発症機序の異なるインドメ タシン誘発胃粘膜損傷に対する作用を検討したとこ ろ，エタノールの場合と同様に強い活性が認められ， 1-ブタノール移行部エキスに活性が集約した。し かし，酢酸エチルや水移行部には活性は認められな かった (Tables 1 and 2).

日本産茶花の1-ブタノール移行部エキスの主要 成分である floratheasaponin A (1) , B (2) , C (3) に ついてエタノール誘発胃粘膜損傷の抑制活性を検討 したところ，比較対照薬である cetraxate hydrochlorideよりも強い保護作用のあることが判明した (Table 3).

1-2. 抗糖尿病作用 チャ葉部のポリフェノー ル成分に糖吸収抑制作用が報告されていることか ら，葉部と共通するポリフェノールを含有する茶花 メ夕ノール抽出エキスにも糖吸収抑制活性が期待さ れた。そこで，ラットレンズ由来アルドース還元酵 素及び $\alpha$-glucosidase 阻害作用を検討した結果，い ずれの酵素に対する阻害作用は弱いものであった (Table 4)。しかし，茶花メ夕ノール抽出エキス は，ショ糖負荷での血糖值上昇を有意に抑制し (Table 5)，ポリフェノールが主成分である酢酸エ チル移行部エキスと floratheasaponin 類が主成分で ある1-ブタノール移行部に活性が認められた。茶 ポリフェノール類の糖吸収抑制作用については既に 知られていることから，茶花特有成分である floratheasaponin（1-3）について検討したところ, いずれの化合物にも強い抑制活性が認められた (Table 6).

\section{Floratheasaponin 類の定性，定量分析}

2-1. Floratheasaponin 類の定性分析 分離条 件を種々検討したが，floratheasaponin A-F（1-6) の 6 成分を完全に分離する HPLC 条件を見い出す ことはできなかった，その中で最もよい分離を示し た分析条件 2-4-2 項の 1) で日本，中国，インド産茶 花の floratheasaponin 類を分析した結果を Fig. 1 に 示した.この分析条件は定量分析に適用することは 困難であったが，各 floratheasaponin（1-6）の存在 が確認できることが明らかになつた。本 HPLC 条 
Table 1. Effects of the MeOH Ext. and Its Fractions on Gastric Lesions Induced by Ethanol in Rats

\begin{tabular}{lcccc}
\hline \hline \multirow{2}{*}{ Sample } & \multirow{2}{*}{$\begin{array}{c}\text { Dose } \\
\text { (mg/kg, p.o. })\end{array}$} & $n$ & \multicolumn{2}{c}{ Gastric Lesions } \\
\cline { 5 - 5 } Control & - & 7 & $115.7 \pm 13.9$ & Inhibition $(\%)$ \\
$\mathrm{MeOH}$ ext. & 50 & 6 & $66.6 \pm 15.9^{*}$ & - \\
& 100 & 6 & $48.9 \pm 13.3^{* *}$ & 57.7 \\
Control (10\% Tween 80) & 200 & 6 & $13.5 \pm 5.9^{* *}$ & 88.4 \\
EtOAc-soluble fraction & - & 4 & $96.7 \pm 24.3$ & - \\
& 100 & 2 & $111.0 \pm 45.0$ & -14.8 \\
Control & 200 & 3 & $128.4 \pm 39.0$ & -32.8 \\
1-BuOH-soluble fraction & - & 8 & $111.2 \pm 11.8$ & - \\
& 25 & 6 & $55.9 \pm 6.3^{* *}$ & 49.7 \\
& 50 & 6 & $41.2 \pm 9.1^{* *}$ & 62.9 \\
$\mathrm{H}_{2} \mathrm{O}-$-soluble fraction & 100 & 6 & $12.9 \pm 8.4^{* *}$ & 88.3 \\
Control & 200 & 6 & $4.1 \pm 1.9^{* *}$ & 96.2 \\
Cetraxate hydrochloride ${ }^{32)}$ & 200 & 3 & $112.3 \pm 9.9$ & 0.0 \\
& - & 6 & $148.4 \pm 9.8$ & - \\
& 75 & 6 & $87.2 \pm 7.4^{* *}$ & 41.2 \\
& 150 & 6 & $51.0 \pm 4.0^{* *}$ & 65.6 \\
\hline
\end{tabular}

Values represent the means \pm S.E. Significantly different from the control group, ${ }^{*} p<0.05$, ${ }^{* *} p<0.01$.

Table 2. Effects of the MeOH Ext. and Its Fractions on Gastric Lesions Induced by Indomethacin in Rats

\begin{tabular}{|c|c|c|c|c|}
\hline \multirow{2}{*}{ Samples } & \multirow{2}{*}{$\begin{array}{c}\text { Dose } \\
(\mathrm{mg} / \mathrm{kg}, \text { p.o. })\end{array}$} & \multirow{2}{*}{$n$} & \multicolumn{2}{|c|}{ Gastric Lesions } \\
\hline & & & Length (mm) & Inhibition (\%) \\
\hline Control & - & 6 & $112.6 \pm 21.0$ & - \\
\hline \multirow[t]{3}{*}{$\mathrm{MeOH}$ ext. } & 50 & 6 & $50.1 \pm 7.8^{* *}$ & 55.5 \\
\hline & 100 & 6 & $36.2 \pm 9.2^{* *}$ & 67.9 \\
\hline & 200 & 6 & $33.8 \pm 6.6^{* *}$ & 70.0 \\
\hline Control (10\% Tween 80$)$ & - & 4 & $71.2 \pm 12.1$ & - \\
\hline EtOAc-soluble fraction & 200 & 4 & $75.9 \pm 8.9$ & -8.9 \\
\hline Control & - & 6 & $93.6 \pm 12.3$ & - \\
\hline \multirow[t]{4}{*}{ 1-BuOH-soluble fraction } & 25 & 6 & $75.9 \pm 8.9$ & 18.9 \\
\hline & 50 & 6 & $41.2 \pm 7.2^{* *}$ & 56.0 \\
\hline & 100 & 6 & $26.2 \pm 3.8^{* *}$ & 72.0 \\
\hline & 200 & 6 & $19.2 \pm 5.7^{* *}$ & 79.5 \\
\hline $\mathrm{H}_{2} \mathrm{O}$-soluble fraction & 200 & 3 & $105.2 \pm 24.8$ & -11.0 \\
\hline Control & - & 6 & $81.3 \pm 6.7$ & - \\
\hline \multirow[t]{3}{*}{ Cetraxate hydrochloride ${ }^{32)}$} & 75 & 6 & $58.7 \pm 7.5^{*}$ & 27.8 \\
\hline & 150 & 6 & $13.4 \pm 3.2^{* *}$ & 83.5 \\
\hline & 300 & 6 & $1.4 \pm 0.5^{* *}$ & 98.3 \\
\hline
\end{tabular}

Values represent the means \pm S.E. Significantly different from the control group, ${ }^{*} p<0.05{ }^{* *} p<0.01$.

件を用いて，1-6の 6 成分がいずれの産地の茶花に も含有されていることが判明した，保持時間は次の 通りであった。

Floratheasaponin A (1): $29.3 \mathrm{~min}, \mathrm{~B} \mathrm{(2):} 72.4$ $\min , \mathrm{C}(3): 78.4 \mathrm{~min}, \mathrm{D}(\mathbf{4}): 28.5 \mathrm{~min}, \mathrm{E} \mathrm{(5)}: 70.3$ $\min , \mathrm{F}(6): 76.8 \mathrm{~min}$.

また，不完全な分離であったが，ピーク高さを比 較して, 1 と 4,2 と 5,3 と 6 の含量比率を求める と, 中国とインド産茶花のそれぞれの比率はいずれ も約 1 対 1 であったが, 日本産茶花のみいずれも約 
Table 3. Inhibitory Effects of Floratheasaponins A (1), B (2), and C (3) on Gastric Lesions Induced by Ethanol in Rats

\begin{tabular}{lcccc}
\hline \hline \multirow{2}{*}{ Sample } & Dose & & \multicolumn{2}{c}{ Gastric Lesions } \\
\cline { 5 - 5 }$(\mathrm{mg} / \mathrm{kg}, p . o)$. & $n$ & & Length $(\mathrm{mm})$ & Inhibition $(\%)$ \\
\hline Control & - & 9 & $157.0 \pm 15.5$ & - \\
Floratheasaponin A & 5 & 6 & $80.2 \pm 14.7$ & 48.9 \\
& 10 & 6 & $72.9 \pm 11.1^{* *}$ & 57.7 \\
& 20 & 6 & $24.2 \pm 10.2^{* *}$ & 88.4 \\
Floratheasaponin B & 50 & 6 & $0.0 \pm 0.0^{* *}$ & 100.0 \\
& 5 & 6 & $92.8 \pm 24.2$ & 40.9 \\
& 10 & 6 & $55.4 \pm 12.2^{* *}$ & 64.7 \\
Control & 20 & 6 & $24.9 \pm 10.5^{* *}$ & 84.1 \\
Floratheasaponin C & 50 & 6 & $11.5 \pm 7.7^{* *}$ & 92.7 \\
& - & 12 & $163.3 \pm 10.3$ & - \\
& 5 & 6 & $38.0 \pm 7.1^{* *}$ & 76.7 \\
& 10 & 6 & $22.3 \pm 6.8^{* *}$ & 86.3 \\
& 20 & 6 & $18.5 \pm 7.2^{* *}$ & 88.7 \\
\hline
\end{tabular}

Values represent the means \pm S.E. Significantly different from the control group, ${ }^{* *} p<0.01$.

Table 4. Inhibitory Effects of the $\mathrm{MeOH}$ Ext. on Aldose Reductase Activity and Rat Intestinal $\alpha$-Glucosidase Activity

\begin{tabular}{|c|c|c|c|}
\hline \multirow{3}{*}{ Sample } & \multicolumn{3}{|c|}{$\mathrm{IC}_{50}(\mu \mathrm{g} / \mathrm{ml})$} \\
\hline & \multirow{2}{*}{$\begin{array}{l}\text { Aldose } \\
\text { reductase }\end{array}$} & $\begin{array}{c}\text { Rat } \\
\text { intestinal }\end{array}$ & $\alpha$-glucosidase ${ }^{a)}$ \\
\hline & & Sucrase & Maltase \\
\hline $\mathrm{MeOH}$ ext. & 72 & $>400(31.1 \%)$ & $>400(48.8 \%)$ \\
\hline
\end{tabular}

2 対 1 であった（Table 7）。この結果は茶花の産地 の鑑別に応用可能と考えられる。

2-2. Floratheasaponin 類の定量分析 前述の ように種々分離条件を検討したが，これまでのとこ ろ floratheasaponin A (1) と D (4), B (2) とE (5) 及び C (3) と F（6）の完全に分離可能な条件が見 い出せず, floratheasaponin A-F (1-6) の一斉分析 は困難であった。今回は, floratheasaponin A (1) と D (4) , B (2) と E (5)，C（3）と F（6）がそれぞ れ完全に 1 ピークとなる HPLC 条件 2-4-2 項の 2) を用いて, 1 と 4, 2 と 5,3 と 6 の 3 ピークについ て定量分析した。検量線は floratheasaponin D (4), $\mathrm{E}(5), \mathrm{F}(6)$ を用いて, 1 と 4,2 と 5,3 と 6 の含量 を算出した.

本法を日本産及び中国（安徽省）産茶花中の各サ ポニン含量を求めたところ, Table 8 に示すように
約 1-2\%含有されていることが判明した。なお， floratheasaponin D-F (4-6) の変動係数 $(v=5)$ は もそれぞれ， $1.25 \%, 1.94 \%, 1.84 \%$ あった.

次に, 中国産茶花の開花時期による含量の変化に ついて分析した．茶花の蕾から花弁が落ちるまでの 期間は約 1 週間であるため，蕾が膨らみ始めた 1 日 目から 3 日目までの茶花を $30 \%$ 咲きとし，4 日目か ら 5 日目までの開花直前の茶花を $50 \%$ 咲きとし， 全開した花を $100 \%$ と表した。開花時期よる floratheasaponin 類の含量変化は Fig. 2 と Table 8 に示した。本分析条件で，分析時間は 30 分以内に 抑え，定量が可能になった。蕾期に含有される floratheasaponin 類の含量は少ないが，30\%咲きに なると蕾期に比べ floratheasaponin 類の含量が約 2 倍まで増加した。 また，floratheasaponin 類は雌ず い（めしべ）に多く含まれていることが明らかとな った。同じ株から得た茶葉には上記 $\mathbf{6}$ 成分を始め, floratheasaponin 類も検出することはできず, floratheasaponin 類は茶花の特有成分であることと ともに，茶葉におけるサポニン含量も茶花に比べて 非常に少ないことが確認された。

\section{2-3. Caffeine の定量分析 茶に含まれる特徵} 成分である caffeine についても合わせて分析した. 中国産の開花時期別茶花サンプル及び同じ株で得た 茶葉の caffeine 含量を分析したところ，いずれの開 
Table 5. Effects of the MeOH Ext. on Increase in Serum Glucose Levels in Sucrose-Loaded Rats

\begin{tabular}{lccccc}
\hline \hline & \multirow{2}{*}{$\begin{array}{c}\text { Dose } \\
\text { (mg/kg, } p . o .)\end{array}$} & $n$ & \multicolumn{3}{c}{ Serum glucose level $(\mathrm{mg} / \mathrm{dl})$} \\
\cline { 5 - 6 } & & & $0.5 \mathrm{~h}$ & $1.0 \mathrm{~h}$ & $2.0 \mathrm{~h}$ \\
\hline Normal & - & 7 & $80.3 \pm 2.8^{* *}$ & $80.0 \pm 2.4^{* *}$ & $83.0 \pm 2.6^{* *}$ \\
Control & - & 7 & $169.3 \pm 3.2$ & $133.1 \pm 2.1$ & $121.0 \pm 3.2$ \\
MeOH ext. & 250 & 6 & $147.7 \pm 3.2^{* *}$ & $137.3 \pm 3.9$ & $122.6 \pm 4.1$ \\
& 500 & 6 & $130.7 \pm 3.0^{* *}$ & $120.3 \pm 2.0^{* *}$ & $123.8 \pm 1.6$ \\
Normal & 1000 & 6 & $124.3 \pm 5.0^{* *}$ & $119.5 \pm 3.9^{* *}$ & $128.3 \pm 2.3$ \\
Control & - & 5 & $85.6 \pm 3.6^{* *}$ & $88.9 \pm 4.1^{* *}$ & $87.1 \pm 2.9^{* *}$ \\
Metformin hydrochloride ${ }^{28)}$ & - & 6 & $159.6 \pm 7.0$ & $145.0 \pm 6.9$ & $110.9 \pm 5.4$ \\
& 125 & 5 & $134.8 \pm 4.3^{*}$ & $136.0 \pm 5.1$ & $115.5 \pm 4.7$ \\
\hline
\end{tabular}

Significantly different from the control, ${ }^{*} p<0.05,{ }^{* *} p<0.01$.

Table 6. Inhibitory Effects of Floratheasaponins A (1), B (2), and C (3) on Serum Glucose Elevation in Sucrose-Loaded Rats

\begin{tabular}{lccccc}
\hline \hline & \multirow{2}{*}{$\begin{array}{c}\text { Dose } \\
\text { (mg/kg, p.o. })\end{array}$} & $n$ & \multicolumn{3}{c}{ Serum glucose level $(\mathrm{mg} / \mathrm{dl})$} \\
\cline { 5 - 6 } & & & $0.5 \mathrm{~h}$ & $1.0 \mathrm{~h}$ & $2.0 \mathrm{~h}$ \\
\hline Normal & - & 15 & $80.3 \pm 2.7^{* *}$ & $100.2 \pm 3.3^{* *}$ & $90.1 \pm 3.1^{* *}$ \\
Control & - & 14 & $147.6 \pm 3.0$ & $138.1 \pm 2.8$ & $107.6 \pm 3.4$ \\
1-BuOH soluble-fr. & 200 & 4 & $131.4 \pm 8.1$ & $138.4 \pm 11.2$ & $111.4 \pm 4.3$ \\
& 500 & 5 & $127.1 \pm 4.9^{* *}$ & $133.7 \pm 4.2$ & $107.7 \pm 8.0$ \\
Floratheasaponin A & 50 & 5 & $122.5 \pm 8.8$ & $130.5 \pm 5.7$ & $118.6 \pm 3.5$ \\
& 100 & 5 & $107.3 \pm 3.6^{* *}$ & $130.9 \pm 5.7$ & $100.5 \pm 6.1$ \\
Floratheasaponin B & 50 & 5 & $120.3 \pm 10.5$ & $135.0 \pm 5.9$ & $123.0 \pm 4.1^{* *}$ \\
& 100 & 5 & $98.4 \pm 7.2^{* *}$ & $105.9 \pm 7.1^{* *}$ & $92.9 \pm 7.4$ \\
Floratheasaponin C & 50 & 5 & $119.8 \pm 7.9^{* *}$ & $132.5 \pm 6.3$ & $109.4 \pm 4.6$ \\
& 100 & 7 & $87.7 \pm 5.5^{* *}$ & $114.9 \pm 4.9^{*}$ & $106.4 \pm 6.4$ \\
\hline
\end{tabular}

Values represent the means \pm S.E. Significantly different from the control group, ${ }^{*} p<0.05,{ }^{* *} p<0.01$.

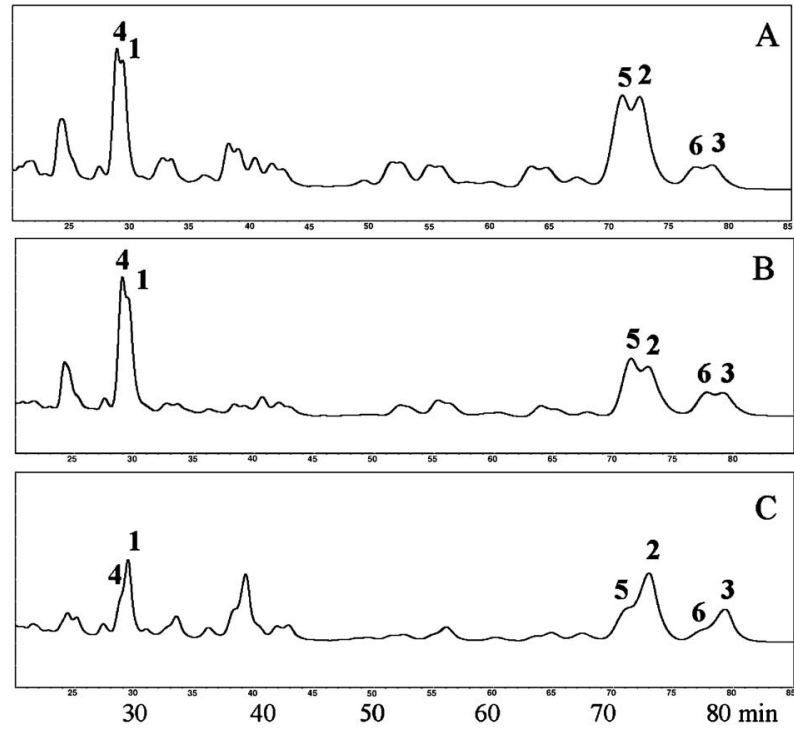

Fig. 1. HPLC Chromatograms of Floratheasaponins A-F (1 -6) of Chinese, Indian and Japanese Tea Flower A: Chinese, B: Indian, C: Japanese.
Table 7. The Ratio of Chromatographic Peak Height of Floratheasaponin A-F (1-6) in Chinese, Indian, and Japanese Tea Flower

\begin{tabular}{lccc}
\hline \hline & $\mathbf{1 , 4}$ & $\mathbf{2 , 5}$ & $\mathbf{3 , 6}$ \\
\hline Chinese & $1: 1.1$ & $1: 1.0$ & $1: 0.9$ \\
Indian & $1: 1.2$ & $1: 1.2$ & $1: 1.1$ \\
Japanese & $1: 0.6$ & $1: 0.5$ & $1: 0.4$ \\
\hline
\end{tabular}

花時期の茶花サンプルもほぼ同程度の caffeine を含 んでいたが，葉と比べ，その含量は半分以下であっ た（Fig. 3） (Table 9).

\section{結 論}

茶葉の栽培生産過程で大量の茶花が副生すること が知られている。茶葉の生産において果実の生成は 好ましいものではないことから一部を除き花蕾の時 
期に除去されていた。地域や栽培条件によって異な るが，1ヘクタールの茶園に新鮮茶花約 $3 \mathrm{t}$ が採取

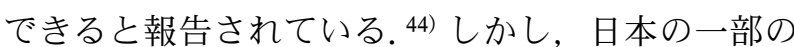
地域で食用とされるほかには未利用であり，また茶 花の含有成分や薬理作用についてはこれまで全く研 究されていない。筆者らは茶花の含有成分や薬理活 性についても研究を行い，茶花の抽出エキスに脂質 負荷マウスでの血中脂肪上昇の抑制作用 ${ }^{37)}$ や抗アレ

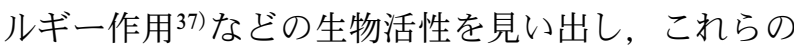
活性はサポニン分画に集約されることが判明した。 さらに，茶花抽出エキスのサポニン分画から 6 種の floratheasaponin 類（1-6）を単離し，それらの化学

Table 8. Floratheasaponins A-F (1-6) Contents (\%) in Tea Flower and Tea Leaf

\begin{tabular}{|c|c|c|c|c|}
\hline & 1,4 & 2,5 & 3,6 & total \\
\hline $\begin{array}{l}\text { Chinese Tea Flower } \\
\text { Bud } \quad(2005, \text { Oct })\end{array}$ & 0.291 & 0.328 & 0.244 & 0.863 \\
\hline $\begin{array}{l}30 \% \text { Bloom } \\
(2005, \text { Oct })\end{array}$ & 0.821 & 0.899 & 0.439 & 2.159 \\
\hline $\begin{array}{l}50 \% \text { Bloom } \\
(2005, \text { Oct })\end{array}$ & 0.747 & 0.690 & 0.515 & 1.952 \\
\hline $\begin{array}{l}50 \% \text { Bloom } \\
(2006, \text { Oct })\end{array}$ & 0.659 & 0.474 & 0.279 & 1.412 \\
\hline $\begin{array}{l}100 \% \text { Bloom } \\
(2005, \text { Oct })\end{array}$ & 0.518 & 0.526 & 0.294 & 1.338 \\
\hline $\begin{array}{l}\text { Japanese Tea Flower } \\
(2004, \text { Jan })\end{array}$ & 0.479 & 0.295 & 0.439 & 1.213 \\
\hline (2005, Oct) & 0.946 & 0.855 & 0.423 & 2.224 \\
\hline Tea-Leaf $\quad(2005$, Oct $)$ & - & - & - & - \\
\hline
\end{tabular}

- : not detected 構造を明らかにするとともに，floratheasaponin 類 に抗肥満作用や抗アレルギー作用が認められ た. ${ }^{37,38)}$ 今回, 日本産茶花のメタノール抽出エキス に弱い $\alpha$-glucosidase とアルドース還元酵素阻害作 用が認められるとともに，エタノール及びインドメ タシン誘発ラット胃粘膜損傷の抑制作用とショ糖負 荷ラットにおける血糖值上昇抑制作用を見い出し た。そして、サポニン分画及び floratheasaponin A （1），B（2）及び C（3）に胃保護作用と血糖值上昇 抑制作用が認められ，日本産茶花エキスの活性本体 であることが判明した。また，主要活性サポニン類 floratheasaponin 類（1-6）について HPLC を用い た定性及び定量法を開発し，この定性分析法を日 本，中国，インド産の茶花（中国種）に適用した結 果，産地により含有成分の種類はほぼ同じである が，組成比が大きく異なることが判明し，本法はチ ヤの産地の判別を目的に応用できると考えられる. また，定量分析法を応用して，茶花の floratheasa-

Table 9. Caffeine Contents (\%) in Tea Flower and Tea Leaf

\begin{tabular}{lc}
\hline \hline & Content \\
\hline Leaf & $2.27 \%$ \\
Bud & $0.82 \%$ \\
Pistil & $0.77 \%$ \\
$30 \%$ Bloom & $0.72 \%$ \\
$50 \%$ Bloom & $0.87 \%$ \\
$100 \%$ Bloom & $0.73 \%$ \\
\hline
\end{tabular}
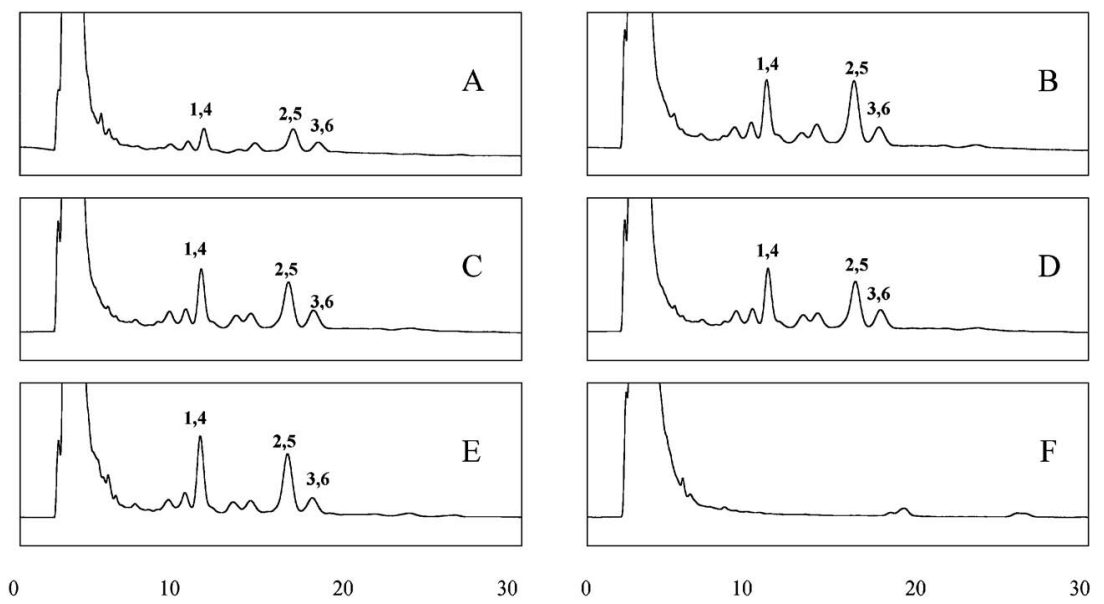

retention time $(\min )$

retention time $(\min )$

Fig. 2. HPLC Chromatograms of Floratheasaponins A-F (1-6) from Chinese Tea Plant A: bud, B: $30 \%$ bloom, C: $50 \%$ bloom, D: $100 \%$ bloom, E: pistil, F: tea-leaf. 

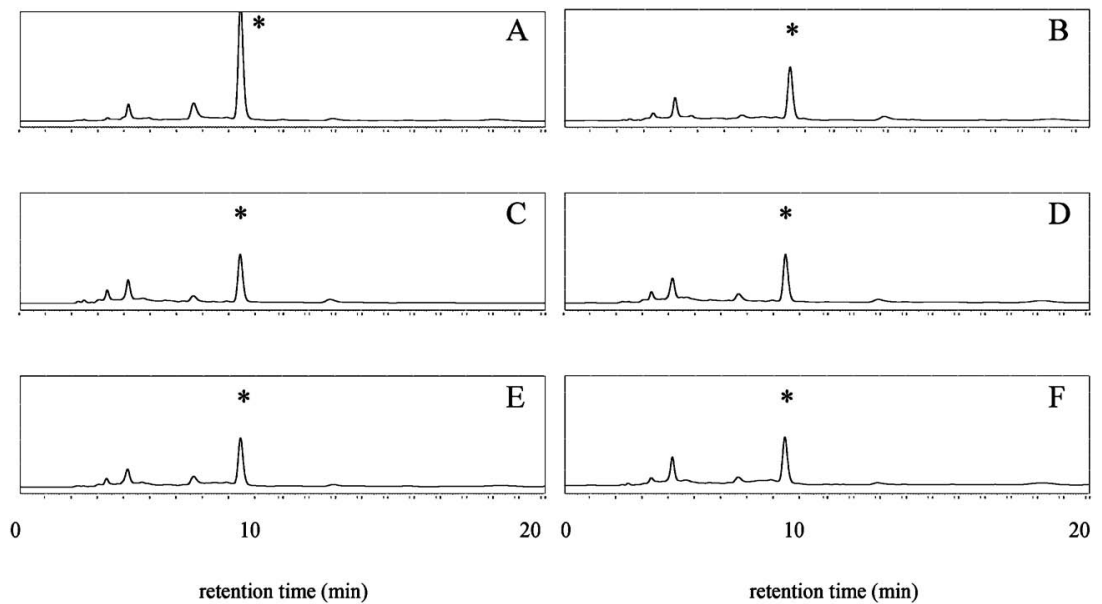

Fig. 3. HPLC Chromatograms of Caffeine from Chinese Tea Plant

A: tea leaf, B: bud, C: pistil, D: 30\% bloom, E: 50\% bloom, F: 100\% bloom. *Peak of Caffeine.

ponin 類含量を明らかにするとともに，茶花の floratheasaponin 類含量は開花時期により変動し, 中国産の 3-5 分咲の花において florathesaponin 含 量が最も多いことが判明した．葉部，花蕾部との比 較のもとに検討したところ, floratheasaponin 類は 葉部には認められず，花蕾部の雌ずい部に局在する ことが確認された。一方，チャの特徵成分である caffeine 含量を調べたところ，茶花の caffeine 含量 は開花時期に係わらず，いずれの場合も葉部と比べ て少なく，その $30 \%$ 程度含有されているに過ぎな いことが判明した。

\section{REFERENCES AND NOTE}

1) This paper is number XVIII in our series from medicinal flower studies. Medicinal Flower XVII: New Dammarane-Type Triterpene Glycosides from Flower Buds of American Ginseng, Panax quinquefoliuml. Nakamura S., Sugimoto S., Matsuda H., Yoshikawa M., Chem. Pharm. Bull., 55, 1342-1348 (2007).

2) Yoshikawa M., Shokuhin to Kagaku, 43, 40$42(2001)$.

3) Yosioka I., Nishimura T., Matsuda A., Kitagawa I., Tetrahedron Lett., 5973-5978 (1966).

4) Tschesche R., Weber A., Wulff G., Justus Liebigs Ann. Chem., 721, 209-219 (1969).

5) Tsukamoto S., Kanegae T., Nagoya T., Shimamura M., Kato T., Watanabe S., Kawaguchi M., Alcohol Alcohol., 28, 687-692 (1993).
6) Sagesaka Y., Uemura T., Suzuki Y., Sugiura T., Yoshida M., Yamaguchi K., Kyuki K., Yakugaku Zasshi, 116, 238-243 (1996).

7) Sagesaka Y., Sugiura T., Miwa Y., Yamaguchi K., Kyuki K., Yakugaku Zasshi, 116, 388-395 (1996).

8) Kitagawa I., Hori K., Motozawa T., Murakami T., Yoshikawa M., Chem. Pharm. Bull., 46, 1901-1906 (1998).

9) Murakami T., Nakamura J., Matsuda H., Yoshikawa M., Chem. Pharm. Bull., 47, 17591764 (1999).

10) Murakami T., Nakamura J., Kageura T., Matsuda H., Yoshikawa M., Chem. Pharm. Bull., 48, 1720-1725 (2000).

11) Yoshikawa M., Morikawa T., Li N., Nagatomo A., Li X., Matsuda H., Chem. Pharm. Bull., 53, 1559-1564 (2005).

12) Morikawa T., Matsuda H., Li N., Nakamura S., Li X., Yoshikawa M., Heterocycles, 68, 1139-1148 (2006).

13) Morikawa T., Li N., Nagatomo A., Matsuda H., Li X., Yoshikawa M., J. Nat. Prod., 69, 185-190 (2006).

14) Yoshikawa M., Morikawa T., Nakamura S., Li N., Li X., Matsuda H., Chem. Pharm. Bull., 55, 57-63 (2007).

15) Li N., Morikawa T., Matsuda H., Ninomiya K., Li X., Yoshikawa M., Heterocycles, 71, 1193-1201 (2007).

16) Morikawa T., Nakamura S., Kato Y., Muraoka O., Matsuda H., Yoshikawa M., Chem. Pharm. Bull., 55, 293-298 (2007). 
17) Shimada S., Nagasawa Y., Komatsubara N., Watanabe H., Ishii Y., "Nihon no Syokuseikatsu Zensyu 32, Hirakisho, Shimane no Shokuji,' Nousangyosonbunkakyoukai, Tokyo, 1991, pp. 327-328.

18) Higuchi K., Tanabe S., Watanabe H., "'Supervised, Aji no Furusato 12, Shimane no Aji,' Kadokawa Shoten, Tokyo, 1978, pp. 13, 31.

19) Yoshikawa M., Shokuhin to Kagaku, 49, 2528 (2007).

20) Yoshikawa M., "Supervised, Development of Medicinal Foods,' CMC Publishers, Tokyo, 2007, pp. 103-109.

21) Yoshikawa M., Morikawa T., Murakami T., Toguchida I., Harima S., Matsuda H., Chem. Pharm. Bull., 47, 340-345 (1999).

22) Yoshikawa M., Morikawa T., Toguchida I., Harima S., Matsuda H., Chem. Pharm. Bull., 48, 651-656 (2000).

23) Matsuda H., Morikawa T., Toguchida I., Harima S., Yoshikawa M., Chem. Pharm. Bull., 50, 972-975 (2002).

24) Yoshikawa M., Murakami T., Kishi A., Kageura T., Matsuda H., Chem. Pharm. Bull., 49, 863-870 (2001).

25) Murakami T., Kishi A., Yoshikawa M., Chem. Pharm. Bull., 49, 974-978 (2001).

26) Matsuda H., Ninomiya K., Shimoda H., Yoshikawa M., Bioorg. Med. Chem., 10, 707712 (2002).

27) Yoshikawa M., Murakami T., Ishiwada T., Morikawa T., Kagawa M., Higashi Y., Matsuda H., J. Nat. Prod., 65, 1151-1155 (2002) .

28) Matsuda H., Morikawa T., Ishiwada T., Managi H., Kagawa M., Higashi Y., Yoshikawa M., Chem. Pharm. Bull., 51, 440-443 (2003).

29) Yoshikawa M., Morikawa T., Kashima Y., Ninomiya K., Matsuda H., J. Nat. Prod., 66, 922-927 (2003).

30) Matsuda H., Morikawa T., Ohgushi T., Ishiwada T., Nishida N., Yoshikawa M., Chem.
Pharm. Bull., 53, 387-392 (2005).

31) Yoshikawa M., Morikawa T., Fujiwara E., Ohgushi T., AsaoY., Matsuda H., Heterocycles, 55, 1653-1658 (2001).

32) Yoshikawa M., Morikawa T., Asao Y., Fujiwara E., Nakamura S., Matsuda H., Chem. Pharm. Bull., 55, 606-612 (2007).

33) Yoshikawa M., Sugimoto S., Nakamura S., Matsuda H., Chem. Pharm. Bull., 55, 571576 (2007).

34) Nakamura S., Sugimoto S., Matsuda H., Yoshikawa M., Heterocycles, 71, 577-588 (2007)

35) Yoshikawa M., Sugimoto S., Nakamura S., Sakumae H., Matsuda H., Chem. Pharm. Bull., 55, 1034-1038 (2007).

36) Yoshikawa M., Xu F., Morikawa T., Pongpiriyadacha Y., Nakamura S., Asao Y., Kumahara A., Matsuda H., Chem. Pharm. Bull., 55, 308-316 (2007).

37) Yoshikawa M., Morikawa T., Yamamoto K., Kato Y., Nagatomo A., Matsuda H., J. Nat. Prod., 68, 1360-1365 (2005).

38) Yoshikawa M., Nakamura S., Kato Y., Matsuhira K., Matsuda H., Chem. Pharm. Bull., 55, 598-605 (2007).

39) Yoshikawa M., Nakamura S., Sugimoto S., Kato Y., Wang T., Matsuda H., Chem. Pharm. Bull. (to be published).

40) Matsuda H., Yutana P., Morikawa T., Kishi A., Kataoka S., Yoshikawa M., Bioorg. Med. Chem. Lett., 13, 1101-1106 (2003).

41) Matsuda H., Ochi M., Nagatomo A., Yoshikawa M., Eur. J. Pharmacol., 561, 172-181 (2007)

42) Yoshikawa M., Pongpiriyadacha Y., Kishi A., Kageura T., Wang T., Morikawa T., Matsuda H., Yakugaku Zasshi, 123, 871-880 (2003).

43) Ding M., Yang H., Xiao S., J. Chromatogr. A., 23, 637-640 (1999).

44) Liang M., Pu S., Sun R., Chin. Tea, 24, 16-17 (2002). 